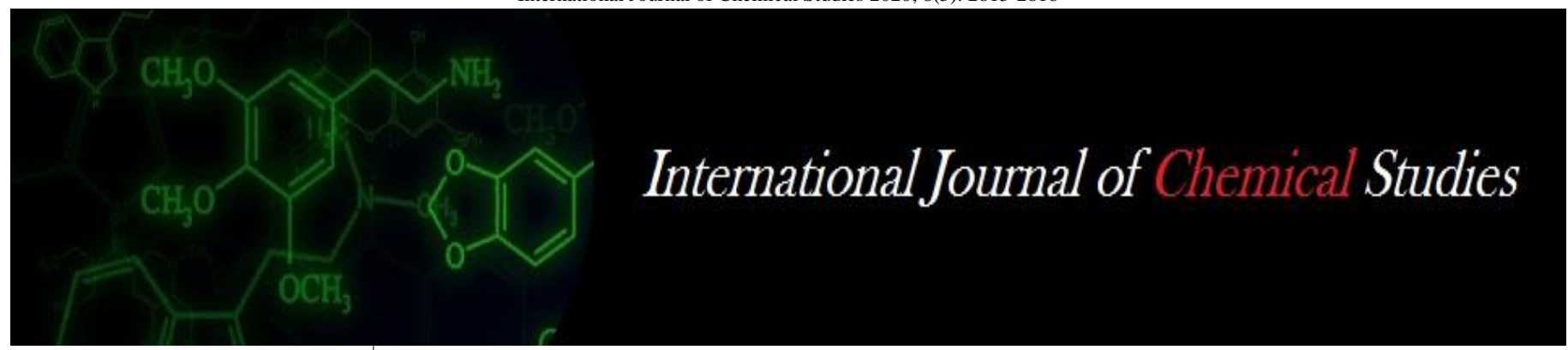

P-ISSN: 2349-8528

E-ISSN: 2321-4902

www.chemijournal.com

IJCS 2020; 8(3): 2813-2816

(C) 2020 IJCS

Received: 06-03-2020

Accepted: 10-04-2020

Gurdarshan Singh

Associate Professor, Hort.,

Krishi Vigyan Kendra, Faridkot,

Punjab, India
Corresponding Author: Gurdarshan Singh

Associate Professor, Hort.,

Krishi Vigyan Kendra, Faridkot,

Punjab, India

\section{Flowering and fruiting behaviour of Bottle gourd as influenced by off-season cultivation under poly film in low tunnel}

\section{Gurdarshan Singh}

DOI: https://doi.org/10.22271/chemi.2020.v8.i3ao.9640

\begin{abstract}
A field experiment was conducted to determine the flowering and fruiting behavior of bottle gourd var Punjab Komal during off season cultivation under low tunnel. The experiment was laid in randomized block design with seven treatments in three replications. The treatments comprised the seven dates of sowings i.e., $15^{\text {th }}$ November and $30^{\text {th }}$ November under low tunnel, $15^{\text {th }}$ and $30^{\text {th }}$ December under tunnel, $1^{\text {st }}$ February, $15^{\text {th }}$ February and $1^{\text {st }}$ March in open field. Results were found to be significant in most of the flowering and yield contributing parameters of bottle gourd. Fruit girth $(8.65 \mathrm{~cm})$, fruit per plant (8.91), yield per plant (3.68 kg), yield per hectare (606.55 quintal), net income (Rs. 341865) and cost benefit ratio (1:3.38) were maximum when the date of sowing was $30^{\text {th }}$ November under low tunnel. Meanwhile number of days taken to first female flower, and first harvest were the minimum when the date of sowing was $30^{\text {th }}$ November under low tunnel. The results suggested that bottle gourd cultivation under poly tunnel accounted for increment in fruit yield and induced precocity due to raised temperature during flowering stage and fruit set. Bottle gourd has high market value in off-season, when crop was sown on $30^{\text {th }}$ November under low tunnel.
\end{abstract}

Keywords: Off-season, low tunnel, date of sowing, profit, bottle gourd

\section{Introduction}

Bottle gourd (Lagenaria siceraria [Mol.] Standl.) belonging to the family Cucurbitaceae, is one of the most important cucurbitaceous crops in India and grown as rainy season as well as summer season vegetable but its fruits are available in the market throughout the year. It is also known as "poor man's vegetable" in India. This delicious vegetable is also known by different names such as quash, calabash gourd, doodhi and lauki, birdhouse gourd, trumpet gourd and white flowered gourd (Thakur et al., 2015) ${ }^{[19]}$.

Bottle gourd is used for preparation of burfi, juice, raita, kofta, doodhi halwa etc. It has a cooling effect and prevents constipation and has diuretic and cardio tonic properties. Regular consumption of this vegetable provides relief to people suffering from digestive problems and used for reducing the blood sugar in diabetic patients. Nutritional value of bottle gourd per 100 $\mathrm{g}$ of edible portion is $96.1 \%$ moisture, $0.2 \mathrm{~g}$ proteins, $0.1 \mathrm{~g}$ fat, $0.5 \mathrm{~g}$ mineral, $0.7 \mathrm{mg}$ fiber, 2.5 g carbohydrates, $12 \mathrm{kcal}$ energy, $20 \mathrm{mg}$ calcium, $10 \mathrm{mg}$ phosphorus, $0.2 \mathrm{mg}$ niacin, $0.01 \mathrm{mg}$ riboflavin, $0.03 \mu \mathrm{g}$ thiamine and it is also rich source of minerals like iron and vitamins like $\mathrm{C}$ and B complex (Singh and Singh, 2014) ${ }^{[16]}$.

The area under bottle gourd cultivation in India is reported to be 185 thousand hectares with annual production of 3072 thousand metric tons. The bottle gourd growing leading states in India are Rajasthan, Gujarat, Punjab, Uttar Pradesh, Bihar, West Bengal, Madhya Pradesh, Maharashtra, Andhra Pradesh and Tamil Nadu (Anon, 2019). Being a warm season crop it is grown successfully in tropical and subtropical areas in open as spring summer, summer and rainy season crop. For more than a decade, off season vegetable cultivation has gained both popularity and attention among vegetable growers of the world. India has also entered in the era of protected vegetable cultivation. The impact of climate change is likely to have a great influence on the agriculture and eventually on the food security. Protected structures i.e., low tunnel can play important role to minimize the impact of temperature fluctuation over precipitation, fluctuating sun shine hour and infestation of disease and pest (Singh and Satpathy, 2005) ${ }^{[18]}$. 
Total area under protected vegetable production in India is not more than 30000 hectares. India being a vast country with diverse and extreme agro- climatic conditions, the protected vegetable cultivation technology can be utilized for year round cultivation of vegetable.

The goal of this study was to investigate poly tunnel technology as a means to improve profitability of fresh market vegetables especially bottle gourd in Punjab. Poly tunnels allow growers to start planting earlier, so they can harvest earlier, and receive a higher price for their produce before vegetable prices begin to decline in mid-season. Poly tunnels benefits in bottle gourd cultivation including: frost protection, earliness in planting and harvesting, and season extension. In fact this technique could be increasingly necessary to mitigate adverse effects of climate change on fruit growing (Carlen and Kruger, 2009) ${ }^{[6]}$. Production under high or low tunnels can improve fruit precocity, allowing growers to get the premium prices usually occurring early in the harvest season (Demchak, 2009) ${ }^{[7]}$. Protecting crops under plastic (polyethylene), either with high tunnels or greenhouses, generates changes in the environmental condition of light, temperature and relative humidity that may have effect on the productive and physiological responses of the plant (Li et al., 2012) ${ }^{[10]}$. Studies have shown that air temperature inside the tunnel is 3 to $20{ }^{\circ} \mathrm{C}$ higher and soil temperature is $2-5^{\circ} \mathrm{C}$ higher than soil temperature recorded in open fields (Ogden and Van Iersel, 2009) ${ }^{[11] . ~ S t u d i e s ~}$ conducted in tomatoes and strawberries indicate that the increases in temperature in high tunnels directly influences fruit precocity, with a harvest starting between 7 to 21 days earlier than in the open field (Wien, 2009) ${ }^{[21]}$. Generally, the tunnels are made in north to south direction to receive maximum sunlight. Transparent plastic of 30-50 micron is commonly used for making low tunnels, which reflects infrared radiation to keep the temperature of the low tunnels higher than outside. These tunnels increase the inside temperature and entrapment of carbon dioxide, resulting in more photosynthetic activity of crops, hence, early produce. They create a favourable microclimate around the crops through frost and pest protection and reducing moisture loss (Butler and Ross, 1999) ${ }^{[5]}$

In several parts of country, especially in northern plains, temperature hovers between 4 to $15{ }^{\circ} \mathrm{C}$ during winter season. So warm season crops like bottle gourd, cucumber etc cannot be cultivated successfully in open field during winter season. Keeping all the above facts in view, the proposed study was planned with the objective to find out best date of sowing and growing condition to get earliest flowering and fruiting in bottle gourd for fetching higher price in market. The outcome will be greater awareness among growers of the potential to use low tunnel technologies to reduce frost risks, and enhance earliness and profitability.

\section{Research Methodology}

The field experiment was conducted in winter season during 2018-19 in the technology park of Krishi Vigyan Kendra, Faridkot. The experimental site was characterized by subtropical climate in which temperature ranges from $2{ }^{\circ} \mathrm{C}$ to $30{ }^{\circ} \mathrm{C}$ during winter. The soil was sandy loam, well drained having $\mathrm{pH} 7.9$, organic carbon $0.72 \%, \mathrm{P}_{2} \mathrm{O}_{5} 12.5 \mathrm{~kg} / \mathrm{ha}$ and available $\mathrm{K}_{2} \mathrm{O} 387.0 \mathrm{~kg} / \mathrm{ha}$. The experiment was conducted in randomized block design in three replications with seven treatments. The treatments comprised of seven dates of sowings i.e., $15^{\text {th }}$ November, $30^{\text {th }}$ November, $15^{\text {th }}$ December and $30^{\text {th }}$ December under low tunnel, I $^{\text {st }}$ February, $15^{\text {th }}$
February and $\mathrm{I}^{\text {st }}$ March under open field. Seedlings of bottle gourd var Punjab Komal were planted on $2.5 \mathrm{~m}$ wide beds at spacing of $60 \mathrm{~cm}$ between plant to plant. For making plastic low tunnel, 50 micron transparent plastic were used, $8 \mathrm{~mm}$ flexible iron rods of 2 meter length shaped into arches/hoops were fixed manually at the distance of 2 meter so as to have the height of 45-60 cm and were pegged on the both sides of water channel. The tunnels were made in north-south direction and vents were made in tunnel on east side. All the necessary cultural practices were carried as per package of practices during the growth period of the crop. In day time plastics are removed from one side of the row and again recovered the row with plastic in the evening time to warm up the plant in presence of sunlight. Plastic of the tunnel was removed from the bed in the 2nd week of February. Ten plants were randomly selected in each treatment for recording various plant growth parameters and yield parameters. Mean values of different characters were used for statistical analysis. The data were recorded on first female flower appearance, first picking, fruit length $(\mathrm{cm})$, fruit girth $(\mathrm{cm})$, fruit weight $(\mathrm{kg})$ and fruits per plant. Mostly artificial soil media was used for raising healthy and vigorous seedlings of vegetable in plastic pro- trays. There were three ingredients viz., cocopeat, vermiculite and perlite which are being used as a rooting medium for raising the nursery. The fruits selected for recording fruit length were used for measuring fruit diameter in centimetres at middle periphery of fruits with the help of Verneer Callipers. The data generated for both growing seasons were pooled together and then analyzed statistically (Panse and Sukhatme 1978) ${ }^{[12]}$.

\section{Research findings and Discussion}

The data presented in Table 2 revealed that bottle gourd cultivation under low tunnel took lesser number of days to first picking and accounted for increment in harvest span, ensured early and good quality yield, thereby, fetching higher price in the market. This is due to the fact that inside the tunnels, plants got better growth as compared to open field. This might be due to the presence of favourable soil and air temperature which increases the better establishment of plants. Temperature difference is largely the result of heat radiation which is trapped by the row covers (Ibarra et al., 2001) ${ }^{[8]}$. Row covers increases air temperature around the crop and their use has been associated with increased plant growth (Akinci et al., 1999; Both et al., 2007; Rader and Karlsson, 2006 and Waterer and Bantle, 2000) ${ }^{[1,3,13,20]}$. The effect of poly tunnels on various reproductive parameters in bottle gourd is presented as below:

\section{Flower attributing parameters}

Days taken to appearance of first female flower and first picking were significantly influenced by the sowing date and growing conditions. Minimum number of days for appearance of first female flower and first harvest were observed when the sowing was done on $30^{\text {th }}$ November under low tunnel $\left(\mathrm{T}_{2}\right)$. Number of days taken for appearance of first female flower was the lowest for $30^{\text {th }}$ November sowing under low tunnel and it was statistically at par with sowing on $1^{\text {st }}$ March under open field. This may be due to favourable warm conditions prevailing under these two treatments which forced earlier appearance of female flowers. All the three treatments under low tunnel were statistically at par with respect to days taken for appearance of first female flower. As far as days to first picking are concerned, sowing under low tunnel on $30^{\text {th }}$ November recorded the earliest picking (67.6 days after 
sowing) followed by sowing on $15^{\text {th }}$ December under low tunnel (69.3 days). All the three treatments under tunnel recorded significantly earlier picking as compared to sowing under open conditions. Thus, sowing under tunnels forces the early harvest of crop which can earn high market value in offseason. The favourable effect of low tunnel on flowering and harvesting might be due to the conducive microclimate condition through which crop had reached to early flowering and fruiting by increasing the temperature at that time. Ogden and van Iersel (2009) ${ }^{[11]}$ have also indicated that low tunnels modify climatic conditions, promoting earlier flowering and fruit ripening as well as fruit precocity. In similar study conducted by Ibarra et al. $2001^{[8]}$ it was observed that muskmelon crop grown under plastic cover flowered 24 days earlier than uncovered plants.

\section{Yield attributing parameters}

Perusal of data presented in Table 2 depicted that fruit length, fruit girth, fruit weight, yield per plant, fruit number per plant and yield per hectare, were significantly influenced by the sowing date and growing conditions. Although, the maximum fruit length was obtained in sowing of bottle gourd under open field conditions to the tune of $45.03 \mathrm{~cm}$ and $44.87 \mathrm{~cm}$, respectively, under $1^{\text {st }}$ March and $15^{\text {th }}$ February sowing still it was at par with sowing on $30^{\text {th }}$ November under low tunnel $(42.60 \mathrm{~cm})$. Similar trend was observed with respect to fruit girth. It might be due to better growth and development of all yield contributing parameters under low tunnel which increases the net photosynthesis and production of more assimilates available for individual fruit to grow. The better growth of yield attributing characters under $15^{\text {th }}$ Feb and $1^{\text {st }}$ March sowing under open field conditions was ascribed to better weather conditions prevailing at that time. Similar results were also obtained by Singh el al. (1989) ${ }^{[17]}$. It is important to note that minor differences were observed with respect to fruit weight in both the conditions i.e., grown in tunnels and in open field. Low tunnels modify microclimate by raising soil and air temperatures. In general, low tunnels allow shortwave solar radiation to pass through during the day and the plastic material slows long wave radiation from the surface at night. The heat that is absorbed could not easily be passed down into the soil because of the insulation of the air between the low tunnel, plastic mulch, and the soils surface. The interior microclimate is further modified as the tunnel material slows convective mixing over the covered surface, reducing both sensible and latent energy losses from the surface (any condensation that does occur on the plastic will release latent heat and warm the plastic) and increasing the ground heat flux.

The present investigation also revealed that total fruit yield was significantly higher under low tunnel on $30^{\text {th }}$ November sowing $(606.55 \mathrm{q} / \mathrm{ha})$ than open field. Buczkowska et al., (1994) ${ }^{[4]}$ revealed that total yield under low tunnel was higher than under open conditions. Sari et al., (1994) ${ }^{[14]}$ reported that increase in yield under low tunnel was due to increase in harvesting span in cucumber. Fruit number per plant was recorded more under protected conditions, i.e, $30^{\text {th }}$ November and $15^{\text {th }}$ December sowing under low tunnel and it was significantly higher than open field crop. This is due to the fact that bottle gourd grown under plastic tunnel got favourable conditions for maximum growth, flowering and fruiting in comparison to other treatments resulting in more number of fruits per plant. Kacjan and Osvald (1997) [9] obtained more fruits per plant under plastic tunnel in pepper. They attributed it to the increase in temperature in tunnel during the cold which results in more growth and yield of the crop. Maximum yield in bottle gourd under $\mathrm{T}_{2}$ it might be due to better growth and development of all yield contributing parameters under low tunnel which were due to increase in the net photosynthesis and production of more assimilates being available for individual fruit to grow. Similar results were reported by Singh el al. (1989) ${ }^{[17]}$.

\section{Economics}

The data presented in Table 3 depicted that net income and cost benefit ratio is greatly influenced by date of sowing and growing conditions. Net income and cost benefit ratio was maximum when sowing the crop on $30^{\text {th }}$ November under tunnel. This might be due to early cropping fetching high market value in off-season. Growers typically reported satisfaction with adopting this technology. Among open conditions, sowing on $15^{\text {th }}$ February proved economical.

Table 1: Meteorological data recorded during crop season (November-April)

\begin{tabular}{|c|c|c|c|c|}
\hline \multirow{2}{*}{ Months } & \multicolumn{2}{|c|}{ Minimum Air Temperature ${ }^{\mathbf{0}} \mathbf{C}$} & \multirow{2}{*}{ Relative humidity } & \multirow{2}{*}{ Rainfall (mm) } \\
\cline { 2 - 3 } & Outside & Inside tunnel & 86.5 & 0 \\
\hline November & 10.6 & 24.6 & 93 & 0.6 \\
\hline December & 4.7 & 22.0 & 93 & 6.2 \\
\hline January & 5.3 & 23.5 & 92 & 27.1 \\
\hline February & 7.9 & 24.3 & 87 & 6.8 \\
\hline March & 11.4 & - & 69 & 24.5 \\
\hline April & 19.0 & - & & \\
\hline
\end{tabular}

Table 2: Effect of planting time and growing conditions on growth and yield attributing parameters of Bottle gourd

\begin{tabular}{|c|c|c|c|c|c|c|c|c|}
\hline Treatments (Planting time) & $\begin{array}{l}\text { Appearance of first } \\
\text { Female flower (Days } \\
\text { after sowing) }\end{array}$ & $\begin{array}{l}\text { Days to first } \\
\text { picking }\end{array}$ & $\begin{array}{c}\text { Fruit length } \\
\text { (cm) }\end{array}$ & $\begin{array}{c}\text { Fruit girth } \\
(\mathrm{cm})\end{array}$ & \begin{tabular}{|c|} 
Fruit \\
weight \\
(kg)
\end{tabular} & $\begin{array}{l}\text { Fruit } \\
\text { No./ } \\
\text { vine }\end{array}$ & $\begin{array}{c}\text { Yield/ } \\
\text { plant (kg) }\end{array}$ & $\begin{array}{l}\text { Yield } \\
\text { q/ha }\end{array}$ \\
\hline $\mathrm{T}_{1}$ : Nov $15^{\text {th }}$ (Under low tunnel) & 59.3 & 72.6 & 32.47 & 7.78 & 0.30 & 6.28 & 1.91 & 315.68 \\
\hline $\mathrm{T}_{2}$ : Nov $30^{\text {th }}$ (Under low tunnel) & 56.0 & 67.6 & 42.60 & 8.65 & 0.41 & 8.91 & 3.68 & 606.55 \\
\hline $\mathrm{T}_{3}$ : Dec $15^{\text {th }}$ (Under low tunnel) & 58.0 & 69.3 & 39.40 & 7.20 & 0.42 & 7.02 & 2.93 & 483.58 \\
\hline $\mathrm{T}_{4}$ : Dec $30^{\text {th }}$ (Under low tunnel & 71.5 & 81.7 & 34.17 & 6.82 & 0.46 & 5.98 & 2.73 & 449.70 \\
\hline $\mathrm{T}_{5}:$ Feb $1^{\text {st }}($ Open field $\left.)\right)$ & 65.5 & 87.8 & 34.60 & 6.86 & 0.45 & 6.55 & 2.95 & 487.13 \\
\hline T6: Feb $15^{\text {th }}($ Open field $\left.)\right)$ & 60.5 & 77.8 & $44 . .87$ & 8.35 & 0.45 & 6.84 & 3.08 & 507.72 \\
\hline $\mathrm{T}_{7}$ : March $1^{\text {st }}$ (open field)) & 59.0 & 78.8 & 45.03 & 8.95 & 0.35 & 6.72 & 2.37 & 390.73 \\
\hline $\mathrm{CD}$ at $5 \%$ & 4.30 & 5.21 & 4.46 & 0.46 & 0.09 & 0.40 & 0.31 & 26.11 \\
\hline
\end{tabular}


Table 3: Economics of bottle gourd cultivation under low tunnel and open field condition

\begin{tabular}{|c|c|c|c|c|}
\hline Treatments & Gross cost (Rs/ha) & Gross returns Rs/ha & Net return/ha & $\mathbf{B : C}$ \\
\hline Sowing on Nov 30 under low tunnel & 143375 & 485240 & 341865 & $3.38: 1$ \\
\hline Sowing on Feb $15^{\text {th }}$ in open condition & 117125 & 253875 & 136750 & $2.16: 1$ \\
\hline
\end{tabular}

\section{Conclusion}

The results suggested that low tunnel sowing in bottle gourd accounted for increment in fruit yield and improved precocity due to raised temperature during flowering stage and fruit set. Bottle gourd has high market value in off-season, when crop was sown on $30^{\text {th }}$ November under low tunnel.

\section{References}

1. Akinci S, Akinci IE, Karatas A, Turkmen O. Temperature changes under different protective structures at late autumn and spring periods in Van (Turkey). Acta Horticulturae. 1999; 491:87-9

2. Anon. 2017. Area and Production of Horticultural crops: All India In agricoop.nic.in.

3. Both AJM, Reiss E, Sudal JF, Holmstrom KE, Wyenandt CA, Kline WL et al. Evaluation of a manual energy curtain for tomato production in high tunnels. Hort Technology. 2007; 17:467-472.

4. Buczkowska H, Babik I, Rumpel J. Usefulness of a slidable tunnel in accelerated vegetable growing. $7^{\text {th }}$ International symposium on timing field production of vegetables. Acta Horticulturae. 1994; 371:297-304.

5. Butler BR, Ross DS. Extending the production season for vegetables and small fruits. College of Agriculture and Natural Resources, University of Maryland, 1999, 1-5.

6. Carlen C, Kruger E. Berry production in changing climate condition and cultivation systems: further Reserch requirements. Acta Horticulturae. 2009; 838:225-228.

7. Demchak K. Small fruit production in high tunnels Hort Technology. 2009; 19(1):44-49.

8. Ibarra L, Flores J, Diaz-Perez JC. and yield of muskmelon in response to plastic mulch and row covers. Scientia Horticulturae. 2001; 87:139-145.

9. Kacjan Marsin N, Osvald J. The influence of different cover materials of greenhouses on growth and development of pepper (Capsicum annuum L.). Zbornic Biotehniske-Fakultete-Univerze-v-Ljubljani,- Kmetijstvo. 1997; 69:141-46.

10. Li X, Chen W, Li Y. on photosynthetic characteristics of blueberry in greenhouse. Acta Horticulturae. 2012; 926:315-320.

11. Ogden AB, Van Iersel MW. Southern high bush blueberry production in high tunnels: temperatures, development, yield, and fruit quality during the establishment years. Hort Science. 2009; 44:1850-1856.

12. Panse VG, Sukhatme PV. Statistical methods for Agricultural workers, ICAR, New Delhi, 1978, 328.

13. Radar HB, Karlsson MG. Northern field production of leaf and romaine lettuce using a high tunnel. Hort Technology. 2006; 16:649-654.

14. Sari N, Guler HY, Abak K, Pakyurek Y, Babik I, Rumpel J. Effect of mulch and tunnel on the yield and harvesting period of cucumber and squash. $7^{\text {th }}$ International symposium on timing field production of vegetables, Skierniewice, Poland, 23- 27 August 1993. Acta Horticulturae. 1994; 371:305- 310

15. Singh AA, Synder BC, Deka RK, Patel BK. The effect of microclimate inside low tunnel on off season production of strawberry (Fragaria xananassa Duch), Scientia Horticulturae, 2012.

16. Singh B, Singh SK. Evaluation trial of bottle gourd. The Asian J Hort. 2014; 9(1):116-119, 144:36-41.

17. Singh R, Arora SK, Panditha ML, Kumar J. Effect of plant growth substances on earliness and yield of summer squash (Cucurbita pepo L) Haryana Agric. Univ. J Res. 1989; 19:311-317.

18. Singh RK, Satpathy KK. Scope and adoption of plastic culture technology in north east hill region. In: Agricultural mechanisation in North East India, ICAR, Research Complex for NEH region, Barapani, 2005, 11421.

19. Thakur P, Sharma D, Visen VK, Dash SP. Evaluation of bottle gourd genotypes. Plant Archives. 2015; 15(2):1037-1040.

20. Waterer D, Bantle J. High tunnel temperature observations. $6^{\text {th }}$ Feb. 2000-2010. http://www.usask.ca /agriculture/plant sci/vegetable/resources/veg/ht_temp.pdf>

21. Wien HC. Micro environmental variations within the high tunnel. Hort Science. 2009; 44:235-238. 